\title{
QUALITY OF CONDUCTED TRAINING SYSTEM MODEL
}

\author{
Nikolay Petrov \\ Chief Assistant, Ph.D., National Military University, Veliko Tarnovo, Bulgaria, nikolo_p@abv.bg
}

\begin{abstract}
The quality of a training course can be assessed by the level of the professional training and the possessed professional competencies of the trainees who have completed it, and, if they meet the needs and expectations of the users of qualified personnel, then these users will be satisfied. By considering the level of customer satisfaction from the training of the qualified personnel and the manner in which they cope with their tasks at their workplace applying the professional competences which they have acquired, it can be established to what extent the conducted training corresponds to the set state requirements and whether it is adequate to the labour market needs, i.e. what its quality is.
\end{abstract}

Keywords: Quality of conducted training, education, training system.

\section{INTRODUCTION}

Vasil Levski National Military University serves its graduates and perceives them as the focus of its existence and the key to future. The diploma awarded to the graduates and the promotion to military ranks is an attestation for the successful implementation of the mission of the University (Georgiev, 2019; Georgiev, 2019a).

The specific forms of organization of the training in Special Military Training (SMT) are complex in their nature and, as a rule, they are conducted in field conditions. Such trainings for the specialization Military Communication and Information Systems (MCIS) are the following: tactic, special, tactic-special classes; the complex tactic classes and drills, as well as the practical training in military specialization conducted in the entities for Communication and Information Maintenance (CIM). All of them aim at acquiring the relevant practical experience and improvement of the habits and skills of the trainees in their work with communication and information tools as well as the provision of services. During the training the cadets perform the tasks of the officers in accordance with the specialization which they are trained in, and in accordance with the concept of the particular class or drill.

\section{MODEL OF THE TRAINING SYSTEM IN SPECIAL MILITARY TRAINING}

The elaboration of a model of a particular system is required for the purpose of studying and examining this system and is part of the system analysis. The idea in this case is to organize the acquired knowledge related to the training in Military Communication and Information Systems and thus to provide a detailed description of the training system in Special Military Training (SMT).

The first step of the modelling is the creation of a structural and functional model of the system including its main elements, the relations and the principle of interaction between them. The concept of "structure" expresses the arrangement of the system and the presence of order in the interaction between the 
composing elements, and the function of a system gives an idea about its behaviour and action in the course of time. Thus, the way the original system acts is presented, and special attention is drawn to the training and the outcomes from this training.

The main elements of every system, whose purpose is to provide training and education, are the following:

- Organization of the training process, based on the regulations stipulating the procedure for acquiring education and conducting training together with the structured syllabi and curricula which take into account the previous education levels and forecast the following ones;

- The human resources, including the academic staff, administrative and servicing staff and trainees;

- The training and material resources comprising all used material and non-material resources for the implementation of the training process;

- Technology of the training - built on the principles, methods and forms of training, representing a selection of organizational forms which make up the structural appropriateness and effective training methods for organizing the learning activities of the trainees in view of the successful acquisition of competences;

- The presence of a quality management system.

Based on the above the model of the training system in Special Military Training (SMT) will look like the diagram in Figure 1.

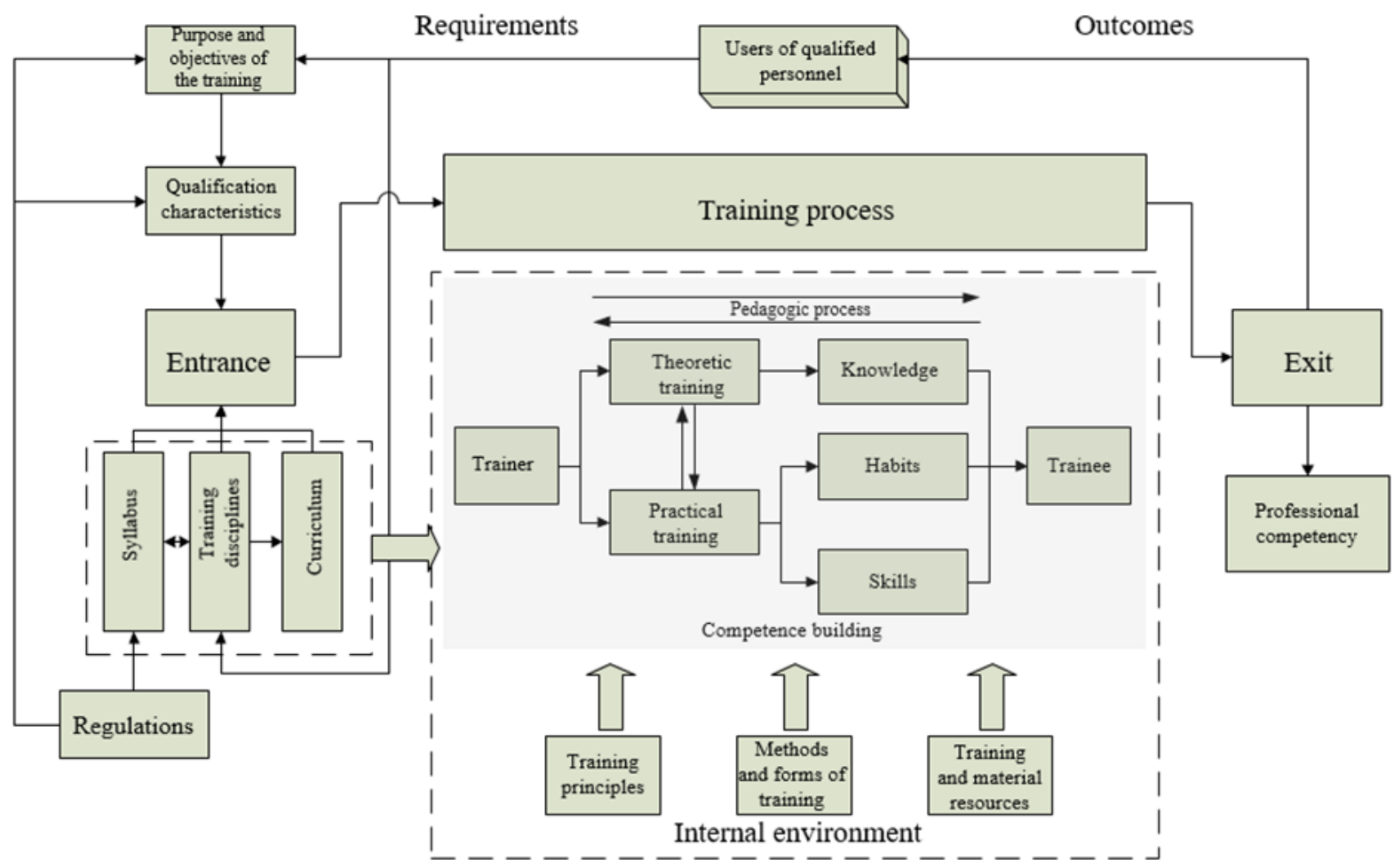

Figure 1. Model of the training system in Special Military Training (SMT).

The "Entrance" of the system is the combination of requirements stipulated in (2013), the purpose and objectives of the training, the syllabus that it will follow, the training content, the literacy level of the trainees and the available resources of the educational institution. An important document for planning, organizing and managing the training process is the Qualification Characteristics (QC). It determines the professional function of the graduates of the speciality "Officer for tactic management level" with educational-qualification degree "Bachelor" as well as their opportunities for career development. Every change in the regulations concerning the requirements for the preparation of the newly graduated officers is reflected in this document. In this relation the Qualification Characteristics is an open document which is updated in accordance with the reforms in the Ministry of Defence and the needs of the military entities.

The training in Special Military Training (SMT) is conducted at the Communication and Information Systems Department at the General Military Faculty through the pedagogic process whose function is to build special competencies. This pedagogic process is specific for its purposes and objectives, content, organization and 
methods and is intended to prepare the graduates for a specific type of military activity and effective actions in a tactical situation. Its structure comprises interrelated units, each of them being an inseparable element of the internal environment in which it is implemented. Its main elements are the theoretical and practical training, conducted by the trainer during the training process for the purpose of providing special training to the trainees (subjects of the training) which is required for their future practical activity. These trainings are the tool through which the graduates receive knowledge and form the skills comprising the competencies which determine the professional capacity of the graduates which is actually the outcome of the training. What contributes for the implementation of the professional capacity is the inseparable connection between theory and practice; the increase of the relative share of exercises and field drills; the conducting of tacticspecial drills and complex exercises in which trainees take the positions of people on duty, heads of control rooms and troop commanders; the good organization of the military practical trainings; the participation of the graduates in the complex signal drills of the entities; as well as the high level of academic and practical preparation of the trainers.

Indicators of the successful functioning of the training system in Special Military Training (SMT) would be the quantity and the level of the built special competencies in the graduates from this specialization. The extent to which this has been achieved is determined by the users of qualified personnel, i.e. the commanders of entities for Communication and Information Maintenance (CIM), who, through their satisfaction from the special competencies built in the newly appointed officers, provide feedback that shows the level of correspondence between what has been planned and what has been achieved in the training in Special Military Training (SMT). By carrying out such a study it will be possible to establish the quality of the pedagogic process in Special Military Training (SMT), the weaknesses in the training, as well as the opportunities for its improvement. This feedback will provide additional information about whether any knowledge and skills necessary for the implementation of a particular position have been omitted in the training, whether any material that is irrelevant to the position is taught, and whether the priorities have been correctly set with regard to capacity building. The requirements from the users of qualified personnel regarding the competencies of the graduates find their reflection in the conducted training, and, based on them, the objectives and the content of the training in Special Military Training (SMT) are set (Glushkov, Simeonov, Georgiev, 2018; Glushkov, Simeonov, 2018a-b).

Figure 1 shows that the pedagogic process through which the special competencies are built in the trainees depends on the following elements of the system for training in Special Military Training (SMT): syllabus and training content; the principles, methods and forms used in the training in SMT; the training and material resources providing for the training process, and the preparation of the academic staff conducting the training in SMT.

\subsection{Principles, Methods and Forms of Training in Smt}

In order for the pedagogic process to be successful the requirements for the content, organization and teaching methods in SMT have to be met. In (1980) the following didactic principles related to the military education which fully influence the training in SMT have been specified, and they are as follows:

- Scientific nature of the training;

- Correspondence of the content and the organization of the training in a System for Higher Military Education to the needs of the professional activity of an officer;

- Demonstrativeness of the training;

- Systematic, coherent and integrated nature of the training;

- Training with high level of difficulty;

- Durability of the acquired knowledge and skills.

The principle of scientific nature of the training requires that during their training the cadets should be provided with strictly scientific knowledge, facts, conclusions and objective laws in accordance with the latest achievements in the respective area of studies. The nature of the officer's activity requires from him to know the military equipment and the arms, their capacities and methods of use. This requires, in accordance with the principle of correspondence of the content and the organization of the training with the needs of the professional activity, the special training to include study of the communication and information tools and systems, which are used as arms, their operation in the entities and the services they offer.

Another major didactic principle is the systematic, coherent and integrated nature of the training. The systematic nature of the training suggests cohesion in the acquisition of knowledge and skills. An officer who 
has completed the training in the speciality Military Communication and Information Systems (MCIS) will be able to successfully fulfil his duties only if his knowledge and skills are systematised by studied disciplines and interrelated in a single complex. This principle requires the syllabi and curricula to be elaborated in such a way so as to provide for the acquisition of a system of knowledge, habits and skills through optimal cohesion and coherence of the separate disciplines.

The principles specified above are implemented through the methods and forms of training. The training methods are didactically based tools for joint work of the trainer and the trainees. Each method has its mechanisms and peculiarities, and is intended to solve particular training tasks. In the training process in SMT for the acquisition of the training material in the separate disciplines the following methods are applied: oral presentation of the training material (lecture), demonstration, practical work, individual work and exercises. Furthermore, the forms of organization of the training in SMT are related to the organizational aspect of the pedagogic process and they reflect the nature and structure of a specific class, the place and duration of its holding, the used material resources, the activity of the trainees, etc. In view of this dependence, the forms can be grouped into two main categories: general and specific.

The general forms of training include the theoretical and practical classes. The theoretical classes provide for the acquisition of general and specific knowledge, explanation and description of number of events or phenomena or a model thereof in the studied specialization. The practical classes are focused on forming and developing skills and abilities of the trainees to put into practice the acquired knowledge when solving practical tasks and situations related to the military service. During practical classes the acquired theoretical knowledge is systematized, it becomes more in-depth and more stable, also the professional training is improved and the competencies needed to work with the arms, military equipment and regulatory documents are formed.

The specific forms of organization of the training in SMT are complex in their nature and, as a rule, they are conducted in field conditions. Such trainings for the specialization Military Communication and Information Systems (MCIS) are the following: tactic, special, tactic-special classes; the complex tactic classes and drills, as well as the practical training in military specialization conducted in the entities for Communication and Information Maintenance (CIM). All of them aim at acquiring the relevant practical experience and improvement of the habits and skills of the trainees in their work with communication and information tools as well as the provision of services. During the training the cadets perform the tasks of the officers in accordance with the specialization which they are trained in, and in accordance with the concept of the class or drill.

\subsection{Training and Material Resources}

A major specific element of the training in SMT in the specialization Military Communication and Information Systems (MCIS) is the high level of presence of technical equipment, and this requires the availability of modern training and material resources. It is extremely important for this specialization to demonstrate through practical exercises what has been taught, and thus the direct connection between the training and the environment where the graduates will work is established. This requires the use in the training process of specialized rooms and laboratories equipped with technical equipment and apparatuses that are used in the entities for Communication and Information Maintenance (CIM). As the available training and material resources provide for the whole training process, they will be of key importance for conducting quality training in SMT which would guarantee the acquisition of special competencies in accordance with the modern requirements.

The training and material resources available at the Communication and Information Systems Department may be conditionally grouped in the following types (2019b):

- Training-household: this group includes the buildings, classrooms and the interior inside;

- Training-demonstrational: it includes the multimedia projectors, interactive boards, demonstration boards, structural and principle schemes of the studied communication tools, etc.;

- Training-technical: it includes active samples and models of communication tools which the trainees operate during their practical classes and exercises;

- Training-informational: it is an integral part of the training and material resources and it comprises the training literature and teaching aids by which the trainees prepare themselves in the time envisaged for selfpreparation.

- Having made a comparison between the resources required by the training disciplines and the actually available ones, the following conclusions can be drawn regarding the training and material resources 
available in Communication and Information Systems Department:

- The department has got sufficient number of classrooms with interior which provides for the conducting of a normal training process;

- The available multimedia projectors are with exhausted resources;

- Two interactive boards are used for the training process in all departments of the faculty;

- For the studied apparatuses by block-diagrams, the relevant boards are available.

There are problems with the condition of the training and material resources. The development of communication and information technologies, as well as the tendencies in the development of the methods and tools for armed military actions, require modernization and re-arming with modern communication and information tools and systems. The acquisition of such equipment in the stationary communication and information system, the mobile communication and information system and the entities for Communication and Information Maintenance (CIM) requires their studying in the specialization Military Communication and Information Systems. In order for the trainees to acquire the necessary skills for work, samples of the new equipment have to be provided for the needs of the training process in SMT. As of the present moment the training and material resources of the department include mainly communication equipment of the old analogue generation equipment which is still used in the military forces. This means that during the process of studying the new communication and information tools and building skills for work with them, there are difficulties with providing for the practical exercises. The possession and maintenance of modern equipment like the one used in the entities for Communication and Information Maintenance (CIM) is difficult and expensive, and as a whole it is hard to be purchased for the needs of the department. For this reason the creation of a strong connection between the training institution and the entities where the graduates will be employed is of primary importance. It is our practice to teach in the lectures the intended use, capabilities, technical data, operation modes and the place of a particular equipment in Communication and Information Systems, whereas part of the practical classes and exercises, for which there are no available material resources, are conducted in the respective entities where the cadets work with the apparatuses under the supervision of their trainers and the heads of the communication and information equipment. Also the trainees acquire skills for operation and maintenance of communication and information equipment during the envisaged in the syllabi military practice conducted during their third and fifth year of studies.

The analysis made so far highlights the dependence of the training process in SMT on the material and training resources. The poor provision of modern communication and information equipment entails lower efficiency and worse quality of the training.

The information provision of the training and scientific activity is done mainly through the university library. The aim is to provide continuous improvement of the information resources for training in SMT through the creation of new textbooks and teaching aids and also provision of internet access to them. For the last three years three textbooks and four teaching aids have been published, and they address problems like the organization of radio communication in tactic entities of land troops, the principles for the creation of multiplex systems with military intended use, the protection of classified information, special measurements in the communication and information unit, etc. The newly published teaching literature pays particular attention to the modern digital communication and information systems, their structure, composition, software and documents in accordance with the operational-technical service for planning of communication and information systems in tactic entities (Terziev, Banabakova, Georgiev, 2017-b; Banabakova, Georgiev, 2017c; Banabakova, Georgiev, 2018c; Ivanov, 2014-a).

\subsection{Academic Staff}

The academic staff of the Communication and Information Systems Department is the resource forming the quality of the training in SMT, and therefore the level of special competencies of the cadets who graduate from this specialization and respectively their suitability to work in entities for Communication and Information Maintenance (CIM). What is characteristic of the last five years is the establishment of a number of positive trends in the professional development of the academic staff of the department, and more specifically of the staff conducting the SMT classes, which should be seen as a result from the policy for scientific promotion adopted by the university. It is worth noting that the number of associate professors has increased by $18 \%$, and also the successful procedure for taking the academic position of "Professor" of a member of the department. Lecturers having academic rank in the SMT disciplines have increased by $29 \%$, and the number of those holding a PhD has increased by the same percentage.

The annual work load of the academic staff for the period is on average $133 \%$ of implementation of the 
standards for teaching hours envisaged for exercises.

The above analyses of the elements comprising the training system in SMT show that the system is capable of fulfilling its purpose and objectives. The teaching documentation conforms to the conditions outlined in [35], the specified modules are being studied, and the number of hours exceeds the minimum levels set in the Ordinance, which therefore leads to the achievement of higher results in the cadets' training. The training content included in the SMT module for the specialization Military Communication and Information Systems (MCIS) is consistent with the requirements set by Communication and Information Systems Directorate and Communication and Information Systems Department of land troops. The academic staff possesses the necessary qualities and competencies, however, the development of communication and information technologies and the acquisition of new capabilities by the entities for Communication and Information Maintenance (CIM) through the introduction of modern communication and information equipment requires continuous development of the academic staff. As of the present moment the lecturers in the department raise their qualifications on individual basis, and their participation in courses for further qualification and in trainings conducted by the companies supplying the equipment will contribute for their professional development (Terziev, Georgiev, 2018d, Terziev, Georgiev, 2018e).

\subsection{Trainees}

An important element of the Training System in Special Military Training is the trainees admitted in the specialization Military Communication and Information Systems (MCIS) at whom the pedagogic process is focused. In accordance with Ordinance No. H6/16.02.2016 of the Minister of Defence of the Republic of Bulgaria (2016) stipulating the conditions and procedure for admission of cadets to higher educational institutions, for cadets in the specializations and full-time training for Bachelor degree in professional Military division, the persons eligible for admission are those who have completed their secondary education and have successfully passed the admission exams which include the following: written admission exam or a test in a subject studied in the secondary education, or a general education test; physical test and also a written test in English, French or German language.

The specified admission conditions do not restrict the candidates for cadets in their choice of specialization. Because of the technical nature of the specialization Military Communication and Information Systems (MCIS), important indicators for the success of the trainees would be their mathematical competencies and their basic competencies in the area of natural studies acquired in their previous level of education. An indicator for the presence of these competences in the trainees admitted to the specialization Military Communication and Information Systems (MCIS) can be the results which they have achieved in their secondary education as shown in Figure 2.

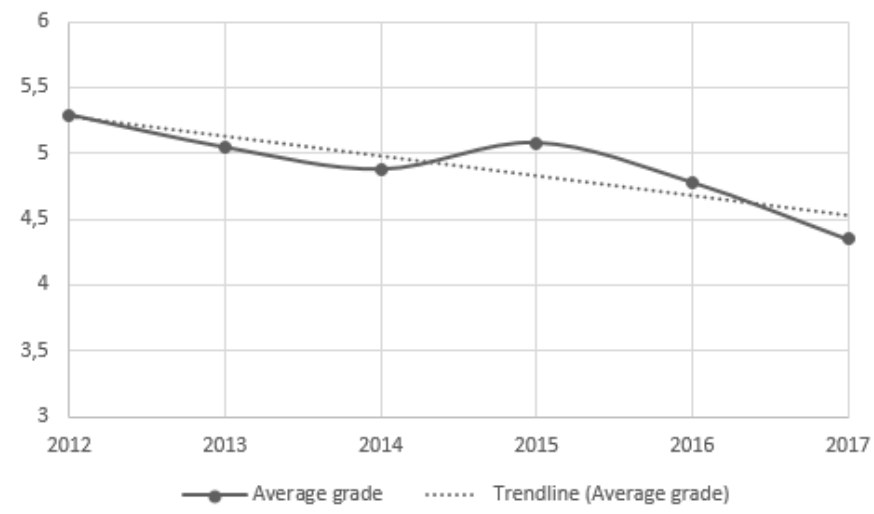

Figure. 2. Average grade from the secondary education of the cadets admitted to the specialization Military Communication and Information Systems (MCIS) by years.

The data used for the elaboration of the diagram is taken from the main books and show a tendency of decrease in the grades for admission of cadets in the specialization. Among the reasons for this we should note the problems and the reform in the system of secondary education, the current demographic crises and the difficulties which the higher educational institutions face for filing up their quotas for trainees, and last but not least, the reduced attractiveness of the military profession.

The intellectual capacities of the trainees have a positive correlation with most of the measurable learning characteristics, because the more capable cadets will apply more complex skills and methods for acquiring the training material (2003). The admission of candidates with lower grade and the varied profiles of secondary education which they have completed suggest different level of knowledge in mathematics, 
natural and technical sciences, which are fundamental for the specialization, undoubtedly affects the training conducted in SMT. This requires at the stage of elaboration of the training process in Military Communication and Information Systems (MCIS), especially the part concerning the academic education, this fact to be considered, and in the selection of disciplines to include such that will provide and will build the necessary volume of knowledge and skills needed for acquiring the SMT. These disciplines should be consistent with the professional division and the civil speciality, and in order to study them the trainees should not have completed any initial specialized training in their secondary education.

The analysis made on the elements of the training system in Special Military Training can set the parameters that characterize the training process, whose condition will determine its quality. The most important of them are the following: training hours in SMT in the syllabus, ratio between lectures and seminars (exercises), level of technical resources for the practical exercises with communication and information equipment, training load during practical training, complexity and adequacy of the theoretical and practical training, qualification of the academic staff, potential and motivation of the trainees (Petrova, Marinov, 2019c; Petrova, 2019d; Petrova, 2010; Petrova, 2008; Atanasov, Mitev, 2016-a; Atanasov, Mitev, 2017d; Atanasov, Stoykov, 2016b).

\section{CONCLUSION}

The following conclusions have been drawn:

The essence of the professional competencies of the future officers is the building of a group of knowledge, skills and qualities that meet the requirements of the military profession.

The training in SMT builds and models a specific area of the professional activity of the future officers and forms their special competencies, the content of which is determined by the objectives, tasks and specifics of the military work in the general and special troops.

The acquisition of new capabilities on the part of the military forces requires improvement of the training in SMT, which can be achieved through updating the syllabi, change in the curricula, raising the professional qualification (professional suitability) of the trainers and last, but not least - the modernization of the training and material resources.

\section{REFERENCE LIST}

Georgiev, Marin. (2019). Balansirana karta za otsenka kato instrument za usavarshenstvane na upravlenieto. Akademiya za inovatsii i ustoychivost, Plovdiv, 2019, 147str., ISBN 978-619-7246-24-7 (Георгиев, Марин. Балансирана карта за оценка като инструмент за усъвършенстване на управлението. Академия за иновации и устойчивост, Пловдив, 2019, 147стр., ISBN 978-6197246-24-7).

Georgiev, Marin. (2019a). Modelat balansirana karta za otsenka kato instrument za usavarshenstvane na upravlenieto vav voennoobrazovatelnata sistema. // Godishna mezhdunarodna nauchna konferentsiya na fakultet „Aviatsionen“ 2019, sbornik dokladi 11 - 12 april 2019g., Natsionalen voenen universitet „Vasil Levski”, Fakultet „Aviatsionen”, Dolna Mitropoliya, str. 451-461, ISBN 978-954-713-123-1 (Георгиев, Марин. Моделът балансирана карта за оценка като инструмент за усъвършенстване на управлението във военнообразователната система. // Годишна международна научна конференция на фракултет „Авиационен“ 2019, сборник доклади 11 - 12 април 2019г., Национален военен университет „Васил Левски”, Факултет „Авиационен”, Долна Митрополия, стр. 451-461, ISBN 978-954-713-123-1).

Naredba za darzhavnite iziskvaniya za pridobivane na visshe obrazovanie na obrazovatelno-kvalifikatsionna stepen „bakalavar“, profesionalno napravlenie „voenno delo“ po spetsialnostite ot reguliranata profesiya "ofitser za taktichesko nivo na upravlenie“ obn. dv. br.68 ot 4 septemvri 2012g., izm. dv. br.62 ot 12 yuli 2013g. (2013) (Наредба за държавните изисквания за придобиване на висше образование на образователно-квалификационна степен „бакалавър“, професионално направление „военно дело“ по специалностите от регулираната професия „офицер за тактическо ниво на управление“ обн. дв. бр.68 от 4 септември 2012г., изм. дв. бр.62 от 12 юли 2013г.)

Psihologiya i pedagogika na vissheto voenno uchilishte, sofiya, voenno izdatelstvo, (1980), Психология и педагогика на висшето военно училище, София, военно издателство, 1980. 
http://old-www.naval-acad.bg/bg/nauch-forum/bulmet03/dokladi/petrov.doc (2019b).

Terzieva, S., Savremenni obrazovatelni strategii, Sofiya, Himikotehnologichen i Metalurgichen universitet, (2003) (Терзиева, С., Съвременни образователни стратегии, София, Химикотехнологичен и металургичен университет, 2003).

Glushkov, P., Simeonov, S., Georgiev, M. (2018). Method of determination of the diurnal energy consumption of the cadets from the Vasil Levski National Military University. // ADVED 2018- 4th International Conference on Advances in Education and Social Sciences Abstracts \& Proceedings, 1517 October 2018- Istanbul, Turkey, International Organization Center of Academic Research, www.ocerints.org, Istanbul, Turkey, 2018, pp. 88-92, ISBN: 978-605-82433-4-7.

Glushkov, P., Simeonov, S. (2018a). Study of the daily energy requirement of the cadets from Vasil Levski National Military University. // ADVED 2018- 4th International Conference on Advances in Education and Social Sciences Abstracts \& Proceedings, 15-17 October 2018- Istanbul, Turkey, International Organization Center of Academic Research, www.ocerints.org, Istanbul, Turkey, 2018, pp. 67-76, ISBN: 978-605-82433-4-7.

Glushkov, P., Simeonov, S. (2018b). Historical analysis of the daily energy requirements of the cadets in the Republic of Bulgaria. // ADVED 2018- 4th International Conference on Advances in Education and Social Sciences Abstracts \& Proceedings, 15-17 October 2018- Istanbul, Turkey, International Organization Center of Academic Research, www.ocerints.org, Istanbul, Turkey, 2018, pp. 77-87, ISBN: 978-605-82433-4-7.

Terziev, V., Banabakova, V., Georgiev, M. (2017). Comparative analysis of the formation of military professional skills in the cadets to be trained in logistics specializations in Bulgaria. // 4th Central \& Eastern European LUMEN International Scientific Conference on Education, Sport and Health 29-30 september 2017, Chisinau, Republic of Moldova, LUMEN, 2017, pp 256-258, ISBN: 978-973-166-4798.

Terziev, V., Banabakova, V., Georgiev, M. (2017a). Analysis and perspectives for the development of the higher education system in Bulgaria. // 4th Central \& Eastern European LUMEN International Scientific Conference on Education, Sport and Health 29-30 september 2017, Chisinau, Republic of Moldova, LUMEN, 2017, pp. 259-260, ISBN: 978-973-166-479-8.

Terziev, V., Banabakova, V., Georgiev, M. (2017b). The Development of academic membership and the development of higher education system in Bulgaria. // 4th Central \& Eastern European LUMEN International Scientific Conference on Education, Sport and Health, 29-30 september 2017, Chisinau, Republic of Moldova, LUMEN, 2017, pp. 261-262, ISBN: 978-973-166-479-8.

Banabakova, V., Georgiev, M. (2017c). Problems and perspectives in Military professional education and realization of cadets in Bulgaria. // Journal of Innovations and Sustainability, Innovations and Sustainability Academy, 3, 2017, N 4, pp. 37-47, ISSN 2367-8127 (CD-ROM), ISSN 2367-8151 (online).

Banabakova, V., Georgiev, M. (2018c). Military professional forming of the cadets at Vasil Levski National Military University. // Proceedings of INTCESS2018- 5th International Conference on Education and Social Sciences 5-7 February 2018- Istanbul, Turkey, International Organization Center of Academic Research, www.ocerints.org, Istanbul, Turkey, 2018, pp. 462-467, ISBN: 978-605-82433-2-3.

Ivanov, Milen. (2014). Nasoki za povishavane nivoto na voenna podgotovka na kursantite, Sbornik dokladi ot godishna universitetska nauchna konferentsiya na NVU „V. Levski“, tom 3, V. Tarnovo, 2014 g., ISSN 1314-1937, str. 38-44 (Иванов, Милен. Насоки за повишаване нивото на военна подготовка на курсантите, Сборник доклади от годишна университетска научна конференция на НВУ „В. Левски“, том 3, В. Търново, 2014 г., ISSN 1314-1937, стр. 38-44).

Ivanov, Milen. (2014a). Formirane na informatsionno-obrazovatelna sreda za voenna podgotovka, Sbornik dokladi ot godishna universitetska nauchna konferentsiya na NVU „V. Levski“, tom 3, V. Tarnovo, 2014 g., ISSN 1314-1937, str. 45-52 (Иванов, Милен. Формиране на информационнообразователна среда за военна подготовка, Сборник доклади от годишна университетска научна конференция на НВУ „В. Левски“, том 3, В. Търново, 2014 г., ISSN 1314-1937, стр. 45$52)$.

Terziev, V., G. Georgiev. (2018d). Savremenni predizvikatelstva i perspektivi v razvitieto na akademichniya sastav vav visshite uchilishta i osobenosti na voennoobrazovatelnata sistema, Institute of Management and Knowledge, Skopje, Macedonia, 2018, ISBN 978-608-4834-03-8, 418 str. 
(Терзиев, В., Г. Георгиев, Съвременни предизвикателства и перспективи в развитието на академичния състав във висшите училища и особености на военнообразователната система, Institute of Management and Knowledge , Skopje, Macedonia, 2018, ISBN 978-608-4834-03-8, 418 стр.).

Terziev, V., G. Georgiev. (2018e). Savremenni predizvikatelstva i perspektivi v razvitieto na akademichniya sastav vav visshite uchilishta i osobenosti na voennoobrazovatelnata sistema, Akademiya za inovatsii i ustoychivost - Plovdiv, 2018, ISBN 978-619-7246-16-2, 429 str. (Терзиев, В., Г. Георгиев, Съвременни предизвикателства и перспективи в развитието на академичния състав във висшите училища и особености на военнообразователната система, Академия за иновации и устойчивост - Пловдив, 2018, ISBN 978-619-7246-16-2, 429 стр.).

Petrova, T., Marinov, M. (2019c). Metodi i algoritmi za obrabotka na aerofoto i radiolokatsionni izobrazheniya, ulesnyavashti analiza na informatsiyata, Vtoro, preraboteno i dopalneno izdanie, Dolna Mitropoliya, 2019 g., ISBN 978-954-713-116-3, 246 str. (Петрова, Т., Маринов, М. Методи и алгоритми за обработка на аерофото и радиолокационни изображения, улесняващи анализа на информацията, Второ, преработено и допълнено издание, Долна Митрополия, 2019 г., ISBN 978-954-713-116-3, 246 стр.).

Petrova, Teodora (2019d). Izsledvane i sintez na algoritmi za obrabotka na radiolokatsionni i optichni izobrazheniya s povisheno kachestvo, Dolna Mitropoliya, 2019 g., ISBN 978-954-713-117-0, 159 str. (Петрова, Теодора, Изследване и синтез на алгоритми за обработка на радиолокационни и оптични изображения с повишено качество, Долна Митрополия, 2019 г., ISBN 978-954-713-1170, 159 стр.)

Petrova, Teodora, (2010). Izpolzvane na programata MULTISIM za poluchavane volt-amperna harakteristika na diod, Sbornik dokladi ot Nauchna konferentsiya „Nastoyashte i badeshte na aviatsionnoto obrazovanie v balkansko-chernomorskiya region na Evropa”, Dolna Mitropoliya 2010 g., str. 133-135, ISBN 978-954-713-094-4 (Петрова, Теодора, Използване на програмата MULTISIM за получаване волт-амперна характеристика на диод, Сборник доклади от Научна конференция „Настояще и бъдеще на авиационното образование в балканско-черноморския регион на Европа", Долна Митрополия 2010 г., стр. 133-135, ISBN 978-954-713-094-4).

Petrova, Teodora (2008). Savmestna lineyna obrabotka na izobrazheniya pri monitoring na okolnata sreda, Sbornik dokladi na Yubileyna nauchna sesiya „100 godini ot obyavyavane nezavisimostta na Balgariya”, Dolna Mitropoliya 2008, str. 421-427, ISBN 978-954-713-092-0 (Петрова, Теодора, Съвместна линейна обработка на изображения при мониторинг на околната среда, Сборник доклади на Юбилейна научна сесия „100 години от обявяване независимостта на България”, Долна Митрополия 2008, стр. 421-427, ISBN 978-954-713-092-0).

Atanasov, M., Mitev, S. (2016). Tochnost na navigatsionnite kompleksi pri stranichno eshelonirane, Sbornik s nauchni dokladi ot parva nauchna konferentsiya s mezhdunarodno uchastie „Edinno evropeysko vazdushno prostranstvo - sashtnost i predizvikatelstvo pred vazdushniya suverenitet i biznesa" gr. Sofiya, VA „G. S. Rakovski”, 11 - 12 oktomvri 2016 g, str.90 - 96, Fondatsiya „Balgarski krile” i „Ear Grup 2000VA" OOD ISBN 978-954-752-175-9 (Атанасов, М., Митев, С. Точност на навигационните комплекси при странично ешелониране, Сборник с научни доклади от първа научна конференция с международно участие „Единно европейско въздушно пространство - същност и предизвикателство пред въздушния суверенитет и бизнеса” гр. София, ВА „Г. С. Раковски”, 11 12 октомври 2016 г, стр.90 - 96, Фондация „Български криле” и „Еър Груп 2000ВА” ООД ISBN 978-954-752-175-9).

Atanasov, M., Mitev, S. (2016a). Tochnost na navigatsionnite kompleksi pri nadlazhno eshelonirane, Sbornik s nauchni dokladi ot parva nauchna konferentsiya s mezhdunarodno uchastie „Edinno evropeysko vazdushno prostranstvo - sashtnost i predizvikatelstvo pred vazdushniya suverenitet i biznesa" gr. Sofiya, VA „G. S. Rakovski”, 11-12 oktomvri 2016 g, str.97 - 110, Fondatsiya „Balgarski krile” i „Ear Grup 2000VA" OOD, ISBN 978-954-752-175-9 (Атанасов, М., Митев, С. Точност на навигационните комплекси при надлъжно ешелониране, Сборник с научни доклади от първа научна конференция с международно участие „Единно европейско въздушно пространство същност и предизвикателство пред въздушния суверенитет и бизнеса” гр. София, ВА „Г. С. Раковски”, 11-12 октомври 2016 г, стр.97 - 110, Фондация „Български криле” и „Еър Груп 2000ВА" ООД, ІSВN 978-954-752-175-9).

Atanasov, M., Mitev, S. (2017d). Opredelyane na rabotnata oblast na dve dalekomerni radionavigatsionni ustroystva, Sb. ot dokladi na NK $2017 \mathrm{~g}$ - „Savremenni tendentsii v aviatsionnoto obuchenie“, fakultet 
„Aviatsionen“ kam NVU, D. Mitropoliya, 18-19.05.2017g., str. 100-107, ISBN 978-954-713-110-1 (Атанасов, М., Митев, С. Определяне на работната област на две далекомерни радионавигационни устройства, Сб. от доклади на НК 2017 г - „Съременни тенденции в авиационното обучение“, фракултет „Авиационен“ към НВУ, Д. Митрополия, 18-19.05.2017г., стр. 100-107, ISBN 978-954-713-110-1).

Atanasov, M., Stoykov, O. (2016b). Tochnost na bombopuskane na metodite indikatsiya tochkata na padane, indikatsiya momenta na puskane i unifitsiraniya metod, $100 \mathrm{~g}$. ot rozhdenieto na k-n Dimitar Spisarevski, fakultet "Aviatsionen", D.M., 2016, s. 46-53,ISBN 978-954-713-109-5 (Atanasov, M., Stoykov, O. Точност на бомбопускане на методите индикация точката на падане, индикация момента на пускане и унифицирания метод, 100 г. от рождението на к-н Димитър Списаревски, фракултет „Авиационен”, Д.М., 2016, с. 46-53,ISBN 978-954-713-109-5). 